\title{
THE AMPHIBIANS AND REPTILES OF RAWA AOPA WATUMOHAI NATIONAL PARK, SOUTHEAST SULAWESI
}

\author{
MOHAMMAD ALI RIDHA $^{1 *)}$, MIRZA DiKARI KUSRINI ${ }^{1)}$, ANI MARDIASTUTI ${ }^{1)}$, AND NANCY KARRAKER ${ }^{2)}$ \\ 1) Department of Forest Resources Conservation \& Ecotourism, Faculty of Forestry and Environment, IPB University, \\ Bogor, 16680, Indonesia \\ 2) Department of Natural Resources Science, University of Rhode Island, Rhode Island, 02881, United States
}

*Email: aliridha18@gmail.com

Accepted January 22, 2021 / Approved August 03, 2021

\begin{abstract}
Rawa Aopa Watumohai National Park (105.194 ha) in Southeast Sulawesi is one of the important conservation areas in Wallacea. This study aimed to measure the diversity of herpetofauna, relative abundance and community similarity in four different habitats. Survey were conducted in January-April 2018 using Visual Encounter Survey (VES) based on time and transects in savanna, riparian, lowland forest, and mangrove. Forty-two species from 17 families were found consisting of 10 species of amphibians and 32 species of reptiles, in which 9 species are endemic i.e. Papurana celebensis and Draco beccarii. The highest diversity $\left(H^{\prime}\right)$ and evenness $(E)$ indexes was found in lowland forest $\left(H^{\prime}=2.497, E=0.555\right)$. The most abundant amphibian was Limnonectes modestus with 85 individuals (23.8\%), while the most abundant reptile was Crocodylus porosus with 24 individuals (6.7\%). The similarity of communities between the four habitats was low $(<0.5)$, indicating that most species are specialists on particular habitats. Although diversity was relatively low in Rawa Aopa Watumohai National Park, high endemism warrants ongoing efforts to conserve amphibians and reptiles in this national park.
\end{abstract}

Key words: herpetofauna diversity, Indonesia, lowland forest, national park, Sulawesi

\section{INTRODUCTION}

Due to its geographical history, Sulawesi is known as an island with high endemicity (Whitten et al., 1987). The diversity of amphibians and reptiles on this island is undoubtely lower than that of other islands in Indonesia, i.e. Sumatra and Kalimantan but with high endemicity (Koch, 2011). The checklist of amphibians and reptiles of Sulawesi is far from complete. Koch (2011) completed the first checklist made by Iskandar and Tjan (1996) and reported 50 species of frogs and 160 species of reptiles in Sulawesi, in which about 1/3 has not been described yet.

There are 72 conservation areas in Sulawesi consisting of 21 nature reserves, 16 wildlife reserves, 9 national parks, 18 natural recreational parks, 4 forest parks, and 4 hunting parks (KLHK, 2017). These areas are important not only conserving the unique landscape of Sulawesi but also the last remaining stronghold for many endemic species. The Rawa Aopa Watomohai National Park in Southeast Sulawesi (105.194 ha) consist of area that represent lowland habitats i.e. mangroves, savannas, peat swamps, lowland rainforest and lower mountain forest. The national park hosts the Aopa marsh, which are the last remaining peat swamp left in Sulawesi (Zwahlen, 1992). There is almost no data on the diversity of amphibian and reptiles in the park, except that the importance of this park for the habitat of Amboina box turtle (Cuora amboinensis) (Widagti, 2007). There is only one report on the occurrence of nine species of herpetofauna within the mangrove area of this park by Setiawan (2016). We provide here the list of amphibians and reptiles of Rawa Aopa Watumohai National Park in
Southeast Sulawesi, including its conservation status and diversity analysis in four habitats within the park.

\section{RESEARCH METHOD}

Sampling was carried out in four types of habitat: savanna, riparian, lowland forest and mangrove within the Rawa Aopa Watumohai National Park, Southeast Sulawesi Province (Figure 1). Rawa Aopa Watumohai National Park is located geographically between $121^{\circ} 44^{\prime}-122^{\circ} 44^{\prime}$ EL and $4^{\circ} 22^{\prime}-4^{\circ} 39^{\prime}$ SL. Administrately it is located in four districts, which are Kolaka Timur, Konawe, Konawe Selatan, and Bombana. The park mostly lies within lowlad area $(0-981 \mathrm{~m})$ and has four types of ecosystems: mangrove ecosystems, lowland forests, swamps, and savannas with diverse topography. The savanna were located at Lanowulu $\left(04^{\circ} 29^{\prime} 01.0^{\prime \prime} \mathrm{SL}\right.$, $122^{\circ} 05^{\prime} 09.3^{\prime \prime} \quad$ EL), Bombana (04³1'01.3" SL, $122^{\circ} 03^{\prime} 37.1^{\prime \prime}$ EL) and Lalembo (04 27'15.2" SL, $122^{\circ} 07^{\prime} 15.1^{\prime \prime}$ EL). The savanna mostly dominated by alang-alang grass (Imperata cylindrical), with vernal pools dotted the landscape. Stream location are Wowulu (04 27'33.5" SL, $122^{\circ} 02^{\prime} 33.7^{\prime \prime} \quad$ EL), Mumbaho (04²7'35.3" SL, 122 02'02.1" EL), and Potuho (04 26'05.0" SL, $122^{\circ} 02^{\prime} 50.9^{\prime \prime}$ EL). Streams are mostly dominated by sandy gravels and rock, with trees and bamboo along the banks. Lowland forest are in Watumohai forest $\left(04^{\circ} 27^{\prime} 50.5^{\prime \prime} \mathrm{SL}, 122^{\circ} 02^{\prime} 26.0^{\prime \prime} \mathrm{EL}\right)$, Howuhowu forest $\left(04^{\circ} 26^{\prime} 06.8^{\prime \prime} \mathrm{SL}, 122^{\circ} 06^{\prime} 00.2^{\prime \prime} \mathrm{EL}\right)$, and Pampaia forest (04'32'15.0" SL, 122 59'48.9" EL). Whereas mangrove forest located at Inandoto 
(04²8'55.2" SL, $122^{\circ} 07^{\prime} 40.4^{\prime \prime} \quad$ EL), Lanowulu (04²9'45.4" SL, $122^{\circ} 05^{\prime} 50.6^{\prime \prime}$ EL) and Mandumandula (04²9'55.1" SL, $\left.122^{\circ} 05^{\prime} 10.6^{\prime \prime} \mathrm{EL}\right)$. The average rainfall ranging from 1,500-2,000 $\mathrm{mm} /$ year and the average temperature is between $22-30{ }^{\circ} \mathrm{C}$. A $25-\mathrm{km}$ provincial road cut through the savanna to connect between Tinanggea and Bombana, developed during EINRIP (The Eastern Indonesia National Road Improvement Project) in 2009.

Data were collected from January to April 2018 during the transitional period between dry and wet seasons. Sampling in savanna was carried out in January 2018 which is considered as dry season. There is no rainfall during that period. Intermittent rain occurred during February to April 2018 when we carried out survey in riparian habitat, lowland forest and mangrove. Since most frogs and reptiles are nocturnal, most frog survey were carried out at night, mostly from 8-10 pm.
Daytime searching was conducted to detect frog egg masses of amphibians, tadpoles and diurnal reptiles, usually between 9-11 am.

We used Visual Encounter Survey (VES) on transect according to Heyer et al. (1994). The length of transect in the stream are $400 \mathrm{~m}$ whereas in terrestrial areas were $1 \mathrm{~km}$ transect. For each habitat, we carried out survey in 3 terrestrial transects and 3 stream transects. The transect are straight lines along the stream where data are collected by walking down the line and counting all amphibians and reptiles seen on either side of the line. If transects in terrestrial habitat is not possible, we used VES at selected time (timed-search), carried out by randomly walking through the selected habitat by twothree investigators and searching for amphibians and reptiles for a total of two hours. Total effort during the research was 312 man-hours, with a range of effort for each habitat 72-84 man-hours.

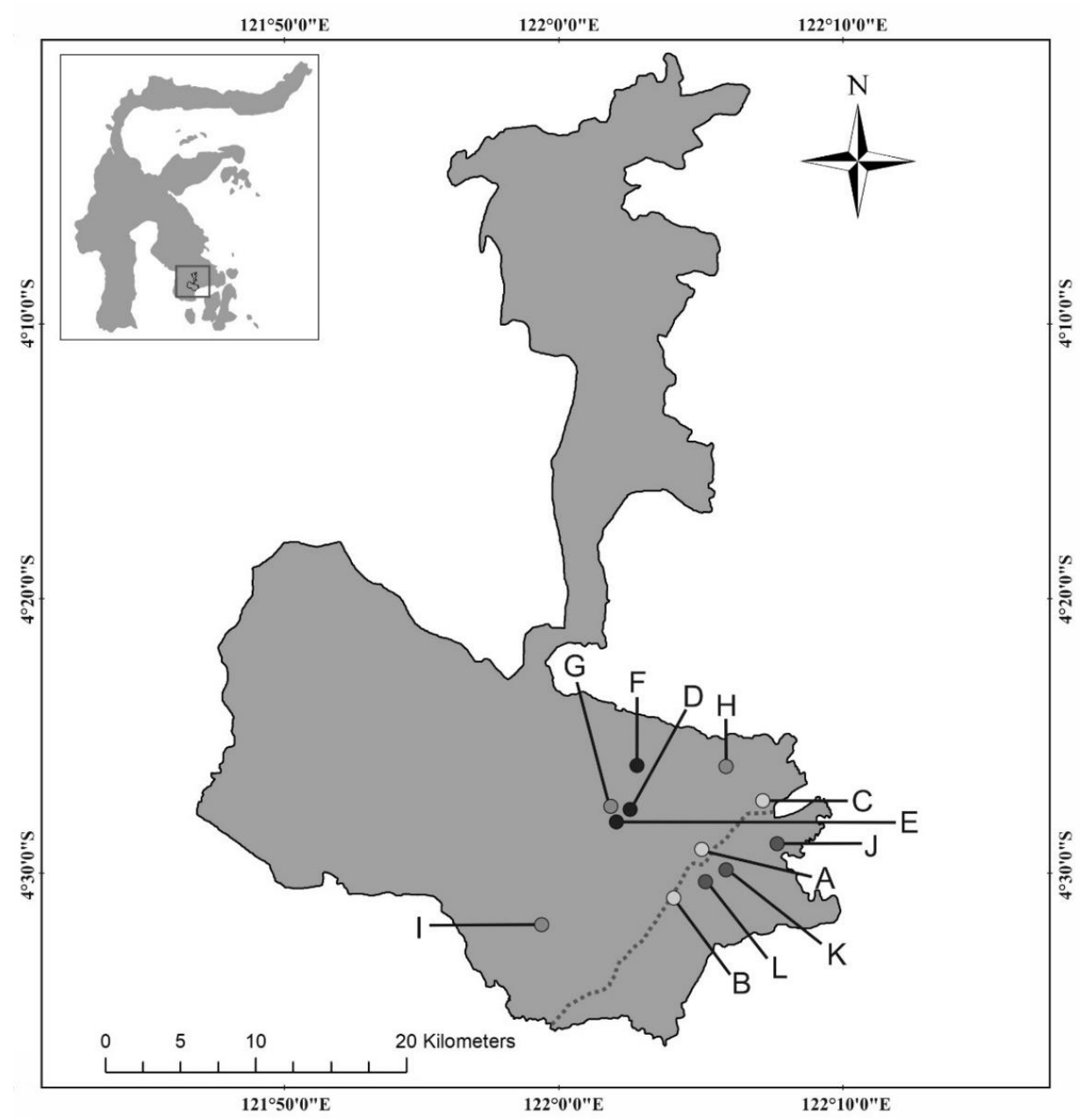

Figure 1 Map of survey area. (A) Lanowulu savanna. (B) Bombana savanna. (C) Lalembo savanna. (D) Wowulu stream. (E) Mumbaho stream. (F) Potuho stream. (G) Watumohai forest. (H) Howuhowu forest. (I) Pampaia forest. (J) Inandoto mangrove. (K) Lanowulu mangrove. (L) Mandumandula mangrove. Dotted lines = provincial road. 
During survey we actively searched the areas within the habitat floor, leaf litter, fallen logs, water bodies, and surrounding vegetation. Each frog and reptiles captured were measured for its weight and snout vent length (SVL or SUL). The measurements were carried out in the location of capture. Direct handling of the species was conducted to determine species, sex and body measurements.

We recorded locations, date of capture, sex (if possible), microhabitat, position along transects, and coordinates at the time of capture. Habitat characteristic were noted. Frogs and reptiles were released after examination at the point of capture. Amphibians were identified using several papers or report on Sulawesi frogs (i.e Brown and Iskandar, 2000; Iskandar et al., 2011a; Kusrini et al., 2015) and likewise for reptiles (i.e. Lang and Vogel, 2005; Kuch et al., 2007; Hayden et al., 2008; Howard et al., 2007; Linkem et al., 2008; Iskandar et al., 2011b; Koch, 2011; Riyanto et al., 2016; Brown et al., 2000; Denzer et al., 2020) and both (Lubis et al., 2008; Wanger et al., 2011). Names assigned for amphibians follows Frost (2020) and for reptiles using Uetz and Etzold (2020).

We constructed a checklist of amphibian and reptiles in the locations and grouped it based on its conservation status: IUCN Red List, CITES Appendix, and Indonesian Law (Peraturan Menteri Kehutanan dan Lingkungan Hidup nomor 106 tahun 2018). We also measured diversity indices using the Shannon-Wiener diversity index (H') and Evenness (E) using program PAST version 3.22 (Hammer et al., 2001). Jackknife estimator for species richness (S) for each station were calculated following Heltse and Forrester (1983).

\section{RESULT AND DISCUSSION}

We identified 10 amphibian species in five families and 32 reptile species in 12 families (Table $1 \&$ Table 2). Reptiles comprised of 2 species of lizards, 5 species of geckoes, 10 species of skinks, one species of turtle, one species of crocodiles, one species of monitor lizard and 12 species of snakes. Two skinks from the genus of Spenomorphus could not be identified to species level. One species of amphibian and seven species of reptiles were found outside transects (Boiga dendrophila gemmicincta, Psammodynastes pulverulentus, Ophiopagus hannah, Hypsiscopus matannensis, Malayophython reticulatus, Varanus salvator, and Xenopeltis unicolor). They were mostly found on or near the provincial road in which some were found in dead form.

While almost all of amphibians are classified as Least Concern (LC) in IUCN Red list (except for Polypedates iskandari), only a third of reptile found are classified in the IUCN Red List. No amphibians are included in the Indonesian protected species list and Appendix of CITES. Two species of reptiles $(C$. amboinensis and $O$. hannah) are categorized as Vulnerable (VU) based on the IUCN red list. Both species with three others, i.e. Crocodylus porosus, M. reticulatus, and $V$. salvator are also listed on CITES Appendix II. Only one species of reptile is protected by Indonesia law, the salt water crocodile Crocodylus porosus. Three species of amphibians (Chalcorana mocquardi, Papurana celebensis, Polypedates iskandari) and six species of reptiles are endemics (Draco beccarii, Cyrtodactylus jellesmae, Eutropis macrophthalma, $B$. dendrophila gemmicincta, Calamaria nuchalis and $H$. matannensis).

The highest species richness was found in lowland forest ( 4 amphibians, 17 reptiles), followed by riparian ecosystems, savanna and mangrove. The number of species found, especially of reptiles, might be increase with the increasing effort as also shown by the Jackknife species richness estimator. Lowland forest has the highest diversity index for reptiles and the mangroves as the lowest with low evenness index, mostly because it is dominated by one species, the saltwater crocodile $(C$. porosus). The value of diversity index for amphibian is quite low, with the highest index in savanna, and the lowest in mangrove (Table 3 ).

The composition of amphibian and reptiles in each habitat differed as shown in the community similarities (Table 4). Only one species of amphibian, the $P$. iskandari and two species of reptiles, Hemidactylus frenatus and $V$. salvator that can be found in three different habitats. Forty percents of amphibian and 51\% of reptiles can only be found in one habitat. The highest abundance for amphibian is Limnonectes modestus (23.8\% from total amphibian) which is mostly found in lowland forest and riparian area. The highest abundance for reptile is Crocodylus porosus which can only found in mangrove (6.7\% from total reptile).

The results showed that each habitat in the national park is important to maintain the diversity of amphibian and reptiles in the area. Any damage or disruption to each of these habitats will resulted in the loss of species, some of which could not be found in other type of habitats. Thus in terms of conservation, each of these habitat is equally important

The aquatic microhabitat within the lowland forest is home for two endemic frogs, Hylarana celebensis and $P$. iskandari. The lowland forest has the highest diversity of reptiles, mostly geckoes and skinks not found in other habitat. The riparian area is near the lowland forest and home for the giant fangless frog, Limnonectes grunniens. Although most of $C$. amboinensis were found in savanna, one turtle was found in this area. It is interesting to study the distribution of this turtle as it was previously only thought as found in the savanna. 


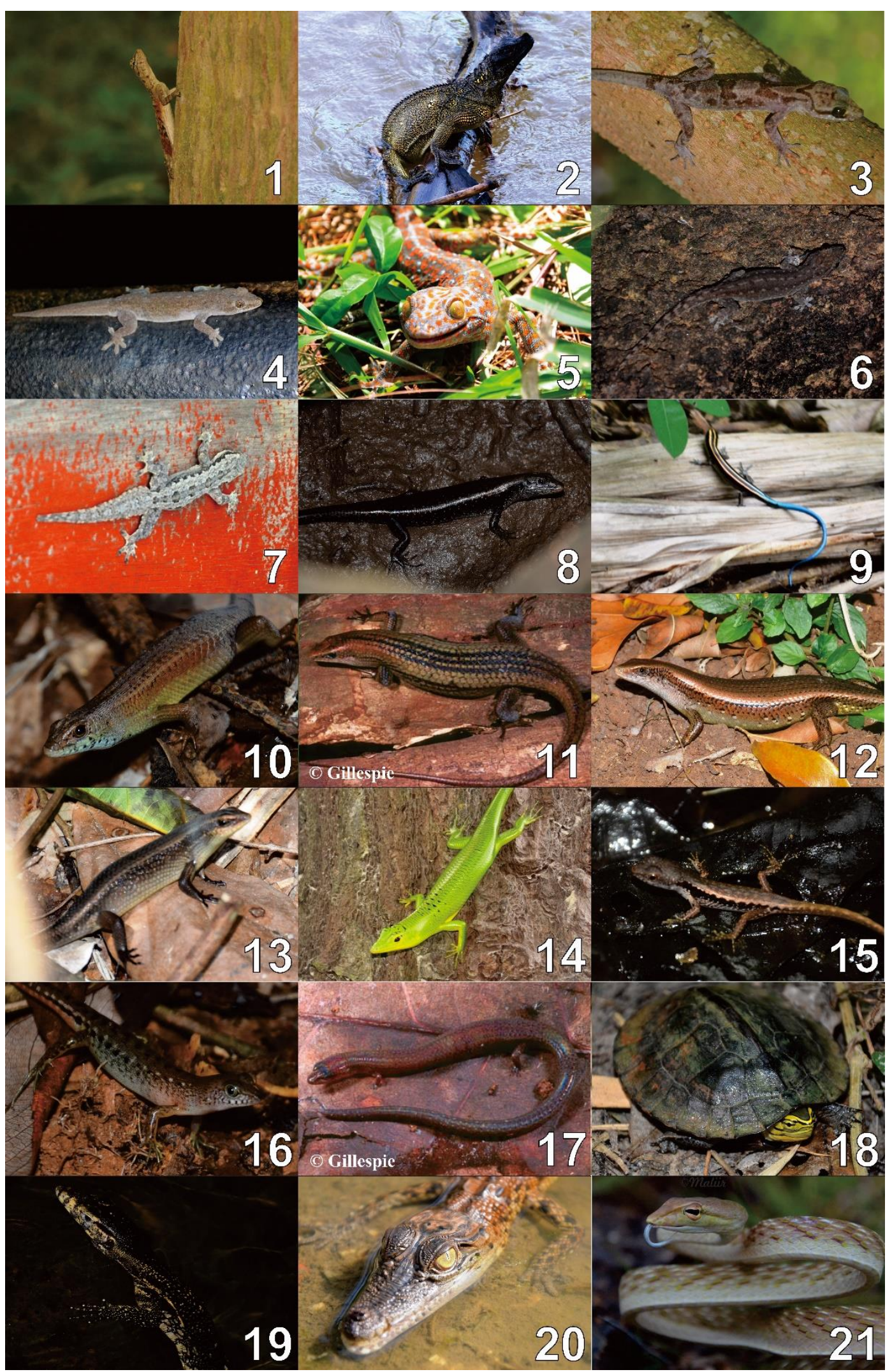






Figure 3 List of Reptiles. (1) Draco beccarii. (2) Hydrosaurus celebensis. (3) Cyrtodactylus jellesmae. (4) Gehyra mutilata. (5) Gekko gecko. (6) Hemidactylus frenatus. (7) Hemidactylus platyurus. (8) Emoia atrocostata. (9) Emoia caeruleocauda. (10) Eutropis indeprensa. (11) Eutropis macrophthalma. (12) Eutropis multifasciata. (13) Eutropis rudis. (14) Lamprolepis smaragdina. (15) Sphenomorphus variegatus. (16) Sphenomorphus sp. 1. (17) Sphenomorphus sp. 2. (18) Cuora amboinensis. (19) Varanus salvator. (20) Crocodylus porosus. (21) Ahaetulla prasina. (22) Boiga dendrophila gemmicincta. (23) Boiga irregularis. (24) Calamaria nuchalis. (25) Dendrelaphis pictus. (26) Psammodynastes pulverulentus. (27) Ophiophagus hannah. (28) Cerberus schneiderii. (29) Hypsiscopus matannensis. (30) Malayopython reticulatus. (31) Virgotyphlops braminus. (32) Xenopeltis unicolor.

Table 1 Amphibian Community Comparison between habitat and conservation status (IUCN Red list and Endemicity). No amphibian is protected under Indonesia Law and included in CITES appendix. Note: Sav = Savanna, Rip = Riparian, LF = Lowlad Forest, Man = Mangrove, OT = outside Transects.

\begin{tabular}{|c|c|c|c|c|c|c|c|c|c|}
\hline \multirow[b]{2}{*}{$\begin{array}{l}\mathrm{N} \\
\mathrm{o}\end{array}$} & \multirow[b]{2}{*}{ Species } & \multicolumn{5}{|c|}{ Habitat } & \multirow[b]{2}{*}{$\mathrm{N}$} & \multirow{2}{*}{$\begin{array}{l}\text { Endemi } \\
\text { cs }\end{array}$} & \multirow{2}{*}{$\begin{array}{c}\text { IUCN Red } \\
\text { list }\end{array}$} \\
\hline & & $\begin{array}{c}\mathrm{Sa} \\
\mathrm{v}\end{array}$ & $\begin{array}{c}\mathrm{Ri} \\
\mathrm{p}\end{array}$ & $\begin{array}{l}\mathrm{L} \\
\mathrm{F}\end{array}$ & $\begin{array}{c}\mathrm{Ma} \\
\mathrm{n}\end{array}$ & $\begin{array}{l}\mathrm{O} \\
\mathrm{T}\end{array}$ & & & \\
\hline \multicolumn{10}{|c|}{ Bufonidae } \\
\hline 1 & Duttaphrynus melanostictus (SCHNEIDER, 1799) & 1 & & & & $\sqrt{ }$ & 1 & No & LC \\
\hline 2 & Ingerophrynus biporcatus (GRAVENHORST, 1829) & 17 & & 1 & & $\sqrt{ }$ & 18 & No & LC \\
\hline \multicolumn{10}{|c|}{ Dicroglossidae } \\
\hline 3 & Fejervarya cancrivora (GRAVENHORST, 1829) & 40 & & & 15 & $\sqrt{ }$ & 55 & No & LC \\
\hline
\end{tabular}




\begin{tabular}{|c|c|c|c|c|c|c|c|c|c|}
\hline 4 & Fejervarya limnocharis (GRAVENHORST, 1829) & 6 & & & & $\sqrt{ }$ & 6 & No & LC \\
\hline 5 & Limnonectes grunniens (LATREILLE, 1801) & & 26 & & & & 26 & No & LC \\
\hline 6 & Limnonectes modestus (BOULENGER, 1882) & & 61 & $\begin{array}{l}2 \\
4\end{array}$ & & & 85 & No & LC \\
\hline \multicolumn{10}{|c|}{ Microhylidae } \\
\hline 7 & Kaloula baleata (MULLER,1836) & & & & & $\sqrt{ }$ & & No & LC \\
\hline \multicolumn{10}{|c|}{ Ranidae } \\
\hline 8 & Chalcorana mocquardi (WERNER, 1901) & & 6 & & & & 6 & Yes & LC \\
\hline 9 & Papurana celebensis (PETERS, 1872) & & 6 & 2 & & $\sqrt{ }$ & 8 & Yes & LC \\
\hline \multicolumn{10}{|c|}{ Rhacophoridae } \\
\hline \multirow[t]{2}{*}{10} & $\begin{array}{l}\text { Polypedates iskandari RIYANTO, MUMPUNI, \& } \\
\text { MCGUIRE, } 2011\end{array}$ & 17 & 6 & $\begin{array}{l}1 \\
1\end{array}$ & & $\sqrt{ }$ & 34 & Yes & NE \\
\hline & Total Species & 5 & 5 & 4 & 1 & & $\begin{array}{c}23 \\
9\end{array}$ & & \\
\hline
\end{tabular}

Table 2 Reptile Community Comparison between habitat and conservation status (IUCN Red list and Endemicity). Note: Sav $=$ Savanna, Rip $=$ Riparian, LF $=$ Lowland Forest, Man $=$ Mangrove, OT $=$ outside Transects

\begin{tabular}{|c|c|c|c|c|c|c|c|c|c|c|}
\hline \multirow{2}{*}{$\begin{array}{l}\mathrm{N} \\
\mathrm{o} .\end{array}$} & \multirow[b]{2}{*}{ Species } & \multicolumn{5}{|c|}{ Habitat } & \multirow[b]{2}{*}{$\mathrm{N}$} & \multirow{2}{*}{$\begin{array}{l}\text { Endem } \\
\quad \text { ics }\end{array}$} & \multirow{2}{*}{$\begin{array}{c}\text { CIT } \\
\text { ES }\end{array}$} & \multirow{2}{*}{$\begin{array}{l}\text { IUCN Red } \\
\text { list }\end{array}$} \\
\hline & & $\begin{array}{c}\mathrm{Sa} \\
\mathrm{V}\end{array}$ & $\begin{array}{c}\mathrm{Ri} \\
\mathrm{p}\end{array}$ & $\begin{array}{l}\mathrm{L} \\
\mathrm{F}\end{array}$ & $\begin{array}{c}\mathrm{Ma} \\
\mathrm{n}\end{array}$ & $\begin{array}{l}\mathrm{O} \\
\mathrm{T}\end{array}$ & & & & \\
\hline
\end{tabular}

\section{Agamidae/Lizards}

1 Draco beccarii PETERS \& DORIA, 1878

2 Hydrosaurus celebensis (PETERS, 1872)

$\begin{array}{lllllll}3 & 4 & \sqrt{ } & 7 & \text { Yes } & \text { No } & \text { NE } \\ & \sqrt{ } & & \text { No } & \text { No } & \text { NE }\end{array}$

\section{Gekkonidae/ Geckoes}

3 Cyrtodactylus jellesmae (BOULENGER, 1897)

4 Gehyra mutilata (WIEGMANN, 1834)

5 Gekko gecko (LINNAEUS, 1758)

6 Hemidactylus frenatus (DUMERIL \& BIBRON, 1836)

7 Hemidactylus platyurus (SCHNEIDER, 1797)

\section{Scincidae/Skinks}

8 Emoia atrocostata (LESSON, 1830)

9 Emoia caeruleocauda (DE VIS, 1892)

10 Eutropis indeprensa (BROWN \& ALCALA,

10 1980)

11 Eutropis macrophthalma (MAUSFELD \&

11 BOHME, 2002)

12 Eutropis multifasciata (KUHL, 1820)

13 Eutropis rudis (BOULENGER, 1887)

14 Lamprolepis smaragdina (LESSON, 1829)

15 Sphenomorphus variegatus (PETERS, 1867)

16 Sphenomorphus sp. 1

17 Sphenomorphus sp. 2

$4 \quad 1$

1

4

4

1

(1)

\section{Chelonidae/Turtles}

18 Cuora amboinensis (DAUDIN, 1802)

\begin{tabular}{|c|c|c|}
\hline 5 & Yes & No \\
\hline 1 & No & No \\
\hline 4 & No & No \\
\hline 3 & No & No \\
\hline & No & No \\
\hline
\end{tabular}

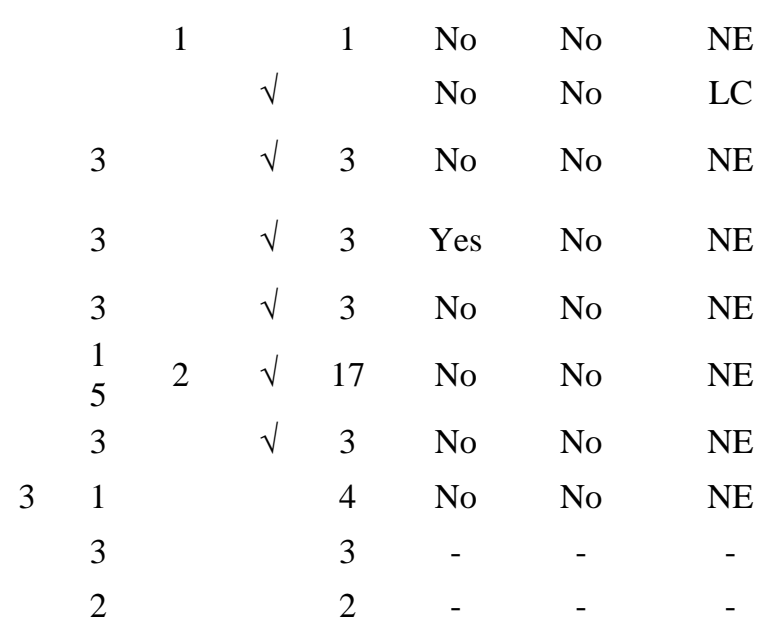




\section{Varanidae}

19 Varanus salvator (LAURENTI, 1768)

\section{Crocodylidae}

20 Crocodylus porosus* SCHNEIDER, 1801

$$
\begin{array}{lllll}
\sqrt{ } & 5 & \text { No } & \text { II } & \text { LC }
\end{array}
$$

\section{Snakes}

\section{Colubridae}

21 Ahaetulla prasina (BOIE, 1827)

22 Boiga dendrophila gemmicincta (DUMERIL \& BIBRON, 1854)

23 Boiga irregularis (BECHSTEIN, 1802)

24 Calamaria nuchalis BOULENGER, 1896

25 Dendrelaphis pictus (GMELIN, 1789)

26 Psammodynastes pulverulentus (BOIE, 1827)

27 Ophiophagus hannah (CANTOR, 1836)

\section{Homalopsidae}

28 Cerberus schneiderii (SCHNEIDER, 1799)

29 Hypsiscopus matannensis (BOULENGER, 29 1897)

Pythonidae

30 Malayopython reticulatus (SCHNEIDER, 1801)

\section{Typhlopidae}

31 Virgotyphlops braminus (DAUDIN, 1803)

\begin{tabular}{|c|c|c|c|c|c|c|c|c|}
\hline & & 3 & & $\sqrt{ }$ & 3 & No & No & LC \\
\hline & & & & $\sqrt{ }$ & & Yes & No & $\mathrm{NE}$ \\
\hline & 1 & & & & 1 & No & No & $\mathrm{NE}$ \\
\hline & & & & $\sqrt{ }$ & & Yes & No & $\mathrm{LC}$ \\
\hline 1 & & 1 & & $\sqrt{ }$ & 2 & No & No & $\mathrm{NE}$ \\
\hline & & 1 & & $\sqrt{ }$ & 1 & No & No & $\mathrm{LC}$ \\
\hline & 1 & & & $\sqrt{ }$ & 1 & No & II & VU \\
\hline & & & 14 & & 14 & No & No & LC \\
\hline & & & 1 & $\sqrt{ }$ & 1 & Yes & No & $\mathrm{NE}$ \\
\hline & 1 & & & $\sqrt{ }$ & 1 & No & II & $\mathrm{NE}$ \\
\hline & & & & $\sqrt{ }$ & & No & No & $\mathrm{NE}$ \\
\hline & 1 & & & $\sqrt{ }$ & 1 & No & No & LC \\
\hline & 9 & $\begin{array}{l}1 \\
7\end{array}$ & 6 & & $\begin{array}{c}11 \\
8\end{array}$ & & & \\
\hline
\end{tabular}




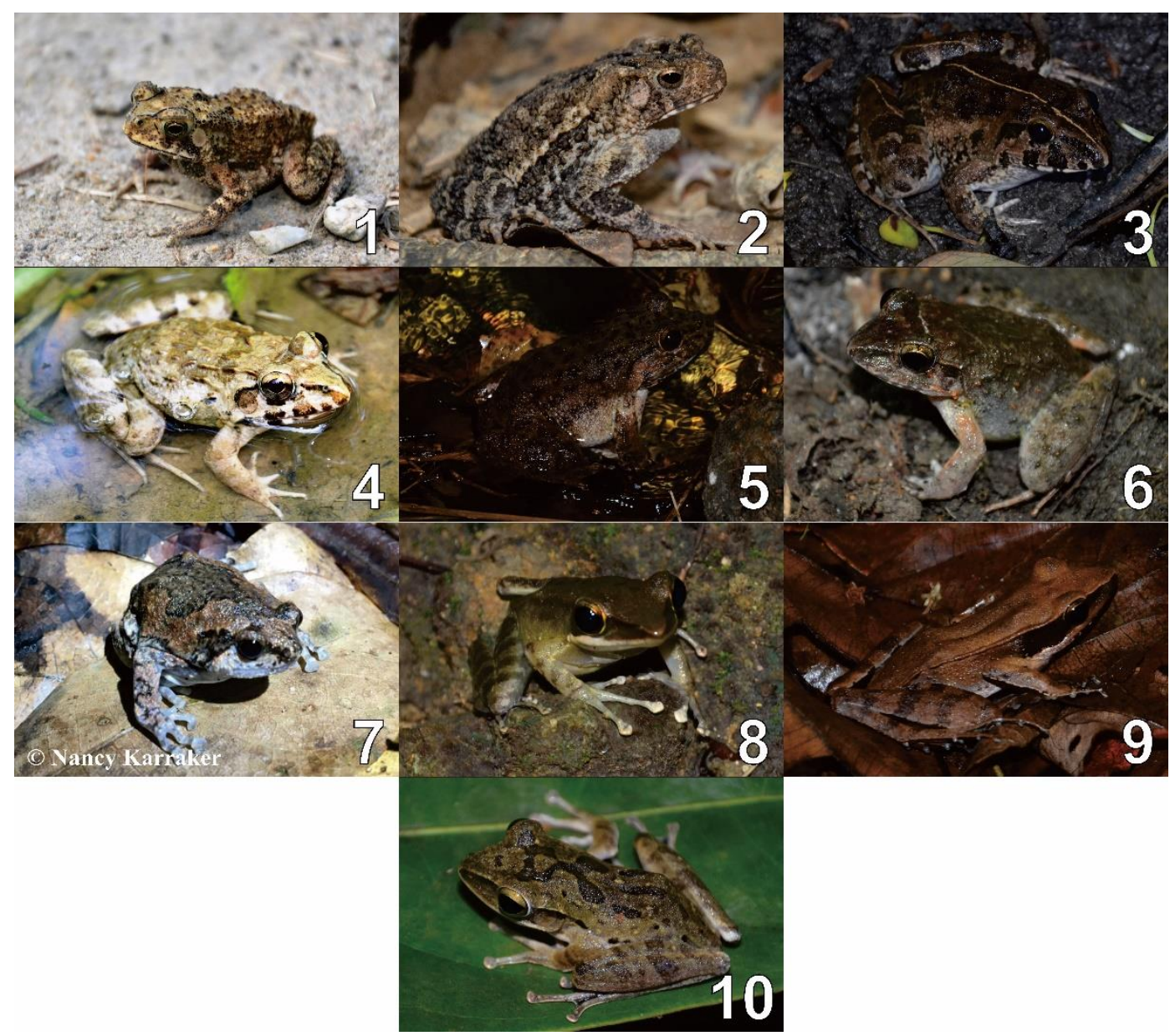

Figure 2 List of Amphibians. (1) Duttaphrynus melanostictus. (2) Ingerophrynus biporcatus. (3) Fejervarya cancrivora. (4) Fejervarya limnocharis. (5) Limnonectes grunniens. (6) Limnonectes modestus. (7) Kaloula baleata. (8) Chalcorana mocquardi. (9) Papurana celebensis. (10) Polypedates iskandari.

Table 3 Number of species, abundance, diversity, evenness and estimated species richness of amphibian and reptiles in four different type of habitat in Rawa Aopa Watumohai National Park.

\begin{tabular}{|c|c|c|c|c|c|c|c|c|c|c|}
\hline \multirow[t]{2}{*}{ Habitat } & \multicolumn{2}{|c|}{ N species } & \multicolumn{2}{|c|}{$\begin{array}{l}\text { Abundance (n/man- } \\
\text { hour) }\end{array}$} & \multicolumn{2}{|c|}{$\mathrm{H}^{\prime}$} & \multicolumn{2}{|c|}{$\mathrm{E}$} & \multicolumn{2}{|c|}{ Jackknife } \\
\hline & Amph & Rept & Amph & Rept & Amph & Rept & Amph & Rept & Amph & Rept \\
\hline Savanna & 5 & 4 & 1.13 & 0.06 & 1.25 & 1.39 & 0.29 & 1.00 & 8 & 8 \\
\hline Riparian & 5 & 9 & 1.25 & 0.23 & 1.15 & 2.01 & 0.25 & 0.68 & 6 & 14 \\
\hline Lowland Forest & 4 & 17 & 0.49 & 0.67 & 0.90 & 2.49 & 0.25 & 0.63 & 6 & 28 \\
\hline Mangrove & 1 & 6 & 0.19 & 0.55 & 0.00 & 1.10 & 0.00 & 0.29 & 1 & 10 \\
\hline Total & 9 & 26 & & & & & & & 11 & 39 \\
\hline
\end{tabular}

Table 4 Community similarity between four types of habitats for amphibian (right side triangle) and reptile (left side triangle) based on index of similarity Bray-Curtis in Rawa Aopa Watumohai National Park.

\begin{tabular}{lcccc}
\hline \multicolumn{1}{c}{ Habitat } & Savanna & Riparian & Lowland Forest & Mangrove \\
\hline Savana & 1.00 & 0.06 & 0.20 & 0.31 \\
Riparian & 0.17 & 1.00 & 0.45 & 0.00 \\
Hutan & 0.11 & 0.23 & 1.00 & 0.00 \\
Mangrove & 0.04 & 0.00 & 0.06 & 1.00 \\
\hline
\end{tabular}


The savanna of the park will become swampy during hard rain, with water retained afterwards in some of the depression areas that formed vernal pools. Vernal pools in savanna, as well stream within lowland forest are important for the habitat of key species of the park, the box turtle, $C$. amboinensis (Widagti, 2007). This highly traded turtles are distributed widely in Southeast Asia but was reported in declines due to habitat change and overharvest (Schoppe, 2008). The vernal pools in savanna also home for some amphibians, i.e Fejervarya cancrivora, Fejervarya limnocharis, Duttaphrynus melanostictus, Ingerophrynus biporcatus and the endemic tree frogs $P$. iskandari. The later usually found in bushes or tress surrounding the stream that connect the pools, most of them were calling and mating. The crab eating frog $F$. cancrivora has the highest abundance in savanna, mostly found around the pools, although it sometimes can be found inside cracked dry soil that developed as holes in the savanna. The frog is also the only species that can be found in mangrove as it is known to be tolerant to brackish water (Gordon et al., 1961).

The mangrove of Rawa Aopa Watumohai is important habitat for the protected saltwater crocodile $C$. porosus with daily sighting of 5-9 crocodyles during three-night survey. The result of the survey in mangrove is lower than study by Setiawan (2016). Three species of amphibians (Occidozyga lima, Ingerophrynus parvus, Odoranna hossii) and one species of reptile, the monitor lizard ( $V$. salvator) is absent during this survey. However, we found five other species absent from Setiawan (2016) study: F. cancrivora, H. frenatus, $C$. rynchops, $H$. matannensis, dan E. rudis. A report from the management Rawa Aopa Watumohai national park (BTNRAW, 2013) listed three other herpetofauna not found during our research: Ingerophrynus celebensis, Rhacophorus monticola, and Gonyosoma jensenii. Thus the total herpeofauna of amphibians and reptiles in the national park will be 48 species. However, species listed from Setiawan (2016) should be re-checked as there is no previous report on Occidozyga lima in Sulawesi which mainly distributed in Java and Bali (Frost, 2020). Cerberus rynchops in Setiawan (2016) is only known to distribute in Borneo (Uetz et al., 2020) and might be misidentification of $C$. schneideri. Increasing effort will undoubtedly increase the possibility of finding more species as shown by the Jackknife species richness estimator. The number of finding in this research is higher than Setiawan (2016) which only conducted in one type of habitat and report from the national park, which is mostly incidental.

Season will also affect the number of species found. Based on the information from the national park office, the rainy season in the national park usually begins in January. However, there is no rain until February, which make most of the area in the savanna quite dry, except for some big pool. During our survey, some of the savanna were burnt, mostly due to human cause. There is a possibility that the absent of reptiles in the savanna were caused by this burn. There is a need to conduct periodic monitoring of amphibian and reptiles in the national park because the possibility of finding other species is still high.

The occurrence of road that divided the savanna habitat into two sections might be one of the cause of reptile mortality. The finding of $B$. dendrophila gemmicincta, a snake that usually inhabits mangrove swamp dead in the road, showed the peril of traffic on the road to wildlife movement. Roads and traffic are one of the main causes of death for wildlife that move because of various reasons, i.e. migration routes, home ranges, or territorial ranges, looking for new food sources, or habitats for some species (Harris and Scheck 1991). Roads are often noted as a barrier that can inhibit animal movement and caused fragmentation of the breeding population (Coffin, 2007). Regions that have a small population with a low number of vehicles may not be at risk of a collision with wildlife (Bennett, 1991), however the road within the park area is a provincial road that connect two districts (Tinanggea and Bombana) with high number of vehicles passing. It is expected that the road might cause death to wild animals, however there is no data on the impact of the road to mortality of wildlife in the area. We suggest a study to be conducted in the are to mitigate any negative impact of road to wildlife.

\section{CONCLUSION}

Rawa Aopa Watumohai National Park is an area that includes a high richness of herpetofauna species, especially in endemic species and is important for the distribution of amphibians and reptiles. There are species that dominate in each habitat. The four habitats have their own uniqueness that makes them important so that their authenticity needs to be maintained because there are many problems that occur in the area that have an impact on the sustainability of the existing herpetofauna species. The results of this study have several implications for herpetofauna conservation.

\section{ACKNOWLEDGMENTS}

Funding for this research is given from Faculty of Forestry and Environment IPB University and University of Rhode Island (URI). Funding from URI is part of research project on "Assessing Populations of a Threatened and Heavily Traded Turtle in Indonesia" funded by Fullbright Research Grant to N. Karraker. We thank the Rawa Aopa Watumohai National Park office, especially the head of the National Park, Bapak Ali Bahri. We thank Acho Bahnur, Serip and Bapak Rigwan who has helped us in the field and Yusratul Aini, Jessica Aututubo, Ryan Healey for their assistance in the field. 
Research in the national park has been granted through the SIMAKSI number SI.05/BTNRAW-1/KK/2018.

\section{REFERENCES}

[BTNRAW] Balai Taman Nasional Rawa Aopa Watumohai. 2013. Buku Informasi Kawasan Taman Nasional Rawa Aopa Watumohai. Sulawesi Tenggara.

Bennett AF. 1991. Roads, roadsides and wildlife conservation: a review. In: Saunders, D.A., Hobbs, R.J. (Eds.), Nature Conservation 2: The Role of Corridors. Chipping Norton, Australia, Surrey Beatty, pp. 99-117.

Brown RM, Iskandar DT. 2000. Nest Site Selection, Larval Hatcling and Advertisement Calls, of Rana arathooni from Southwestern Sulawesi (Celebes) Island, Indonesia. Jurnal of Herpetology. 34 (3):404-413

Brown RM, Supriatna J, Ota H. 2000. Discovery of a New Species of Luperosaurus (Squamata; Gekkonidae) from Sulawesi, with a Phylogenetic Analysis of the Genus, and Comments on the Status of Luperosaurus serraticaudus. Copeia 2000: 191-209.

Coffin AW. 2007. From roadkill to road ecology: A review of the ecological effects of roads. Journal of Transport Geography. 15 (2007) 396-406.

Denzer W, Campbell PD, Manthey U, Glasser-Trobisch A, Koch A. 2020. Dragon in neglect: Taxonomic revision of the Sulawesi sailfin lizards of the genus Hydrosaurus Kaup, 1828 (Squamata, Agamidae). Zootaxa 4747:275-301.

Frost DR. 2020. Amphibian Spesies of the World; an Online Reference. Version 6.0 http://research.amnh.org/herpetology/amphibian. [2020 August 20]

Gordon MS, Schmidt-Nielsen K, Kelly HM. 1961. Ostomic Regulation in the Crab-Eating Frog (Rana cancrivora). Journal of Experimental Biology 38: 659-678.

Hammer O, Harper DAT, Ryan PD. 2001. Paleontological Statistics Software Package for education and data analysis. Palaeontologia Electronica. 4(1):9-18

Harris LD, Scheck J. 1991. From implications to applications: the dispersal corridor principle applied to the conservation of biological diversity. In: Saunders DA, Hobbs RJ, (eds.) Nature Conservation 2: The Role of Corridors. Surrey Beatty, Chipping Norton, Australia, pp. 189-220.

Hayden CJ, Brown RM, Gillespie G, Iqbal Setiadi M, Linkem CW, Iskandar DT, Bickford DP, Riyanto A, McGuire JA. 2008. A new species of bent-toed gecko Cyrtodactylus Gray, 1827, (Squamata: Gekkonidae) from the island of Sulawesi, Indonesia. Herpetologica 64: 109-120.
Heyer WR, Donnelly MA, McDiarmid RW, Hayek LC, Foster MS. 1994. Measuring and Monitoring Biological Diversity: Standard Methods for Amphians. Washington: Smithsonian Institution Press.

Heltse JF, Forrester NE. 1983. Estimating species richness using the Jackknife procedur. Biometrics. 39(1): 1-11

Howard SD, Gillespie GR, Riyanto A, Iskandar DT. 2007. A New Species of Large Eutropis (Scincidae) from Sulawesi, Indonesia. Journal of Herpetology 41: 604-610.

Iskandar DT, Tjan KN. 1996. The amphibians and reptiles of Sulawesi, with notes on the distribution and chromosomal number of frogs. In: Kitchener DJ, Suyanto A, (eds.) Proceedings of the First International Conference on Eastern IndonesianAustralian Vertebrate Fauna. Manado, Indonesia. pp: 39-46.

Iskandar DT, Arifin U, Rachmansah A. 2011a. A new frog (Anura, Dicroglosidae) Related to Occidozyga Semipalmata Smith, 1927, from the Eastern Peninsula of Sulawesi, Indonesia. Raffles Bulletin of Zoology 59: 219-228.

Iskandar DT, Rachmansah A, Umilaela. 2011b. A new bent-toed gecko of the genus Cyrtodactylus Gray, 1827 (Reptilia, Gekkonidae) from Mount Tompotika, eastern peninsula of Sulawesi, Indonesia. Zootaxa 2838: 65-78.

[KLHK] Kementerian Lingkungan Hidup dan Kehutanan. 2017. Statistik 2016 Direktorat Jenderal KSDAE. Direktorat Jenderal Konservasi Sumber Daya Alam dan Ekosistem, Sekretariat Direktorat Jenderal Konservasi Sumber Daya Alam dan Ekosistem. Jakarta.

Koch A. 2011. The amphibians and reptiles of Sulawesi: Underestimated diversity in a dynamic environment. Biodiversity Hotspot: 383-404. doi: 10.1007/978-642-20992-5_20.

Kuch U, Gumprecht A, Melaun C. 2007. A new species of Temple Pitviper (Tropidolaemus Wagler, 1830) from Sulawesi, Indonesia (Squamata: Viperidae: Crotalinae). Zootaxa 1446: 1-20.

Kusrini MD, Rowley JJ, Khairunnisa LR, Shea GM, Altig R. 2015. The reproductive biology and larvae of the first tadpole-bearing frog, Limnonectes larvaepartus. PLoS ONE. 10 (1): e116154. doi:10.1371/journal.pone.0116154.

Lang RD, Vogel G. 2005. The Snake of Sulawesi; A field guide to the land snakes of Sulawesi with identification keys. Frankfrut (DE): Edition Chimaria.

Linkem CW, Mcguire JA, Hayden CJ, Setiadi MI, Bickford DP, Brown RM. 2008. A New Species of Bent-Toe Gecko (Gekkonidae: Cyrtodactylus) From Sulawesi Island, Eastern Indonesia. Herpetologica 64: 224-234. 
Lubis MI, Endarwin W, Riendriasari SD, Suwardiansah, Ul-Hasanah AU, Irawan F, Aziz HK, Malawi A. 2008. Conservation of Herpetofauna in Bantimurung Bulusaraung National Park, South sSulawesi, Indonesia. Bogor (ID): Fakultas Kehutanan IPB.

Riyanto A, Kurniati H, Engilis A. 2016. A new Bent-toed gecko (Squamata: Gekkonidae) from the Mekongga Mountains, South East Sulawesi, Indonesia. Zootaxa 4109: 059-072. http://doi.org/10.11646/zootaxa.4109.1.5

Schoppe S. 2008. Science in CITES: the biology and ecology of the Southeast Asian box turtle Cuora amboinensis and its uses and trade in Malaysia. Traffic Southeast Asia. Petaling Jaya, Selangor, Malaysia.

Setiawan Y. 2016. Keragaman Herpetofauna pada Ekosistem Mangrove Taman Nasional Rawa Aopa Watumohai di Resort Lanowulu, Kecamatan Tinanggea Kabupaten Konawe Selatan. Skripsi Fakultas Kehutanan dan Ilmu Lingkungan Univ. Halu Oleo.
Uetz P, Freed P, Hosek J. 2020. The Reptile Database. http://reptile-database.org. Accessed [2020 August 20]

Wanger TC, Motzke I, Saleh S, Iskandar DT. 2011. The amphibians and reptiles of the Lore Lindu National Park area, Central Sulawesi, Indonesia. Salamandra. 47(1): 17-29.

Whitten AJ, Mustafa M, Handerson GS. 1987. The Ecology of Sulawesi. Yogyakarta (ID): UGM Press.

Widagti N. 2007. Cuora amboinensis Daudin 1802 (Testudines: Geomydidae) di kawasan dilindungi (Taman Nasional Rawa Aopa Watumohai, Sulawesi Tenggara) dan di kawasan eksploitasi (Kecamatan Kota Bangun, Kabupaten Kutai Kartanegara, Kalimantan Timur): karakteristik morfologi, kelimpahan, dan pemanenan. [tesis]. Depok (ID): Universitas Indonesia.

Zwahlen R. 1992. The Ecology of Rawa Aopa, a Peatswamp in Sulawesi, Indonesia. Environmental Conservation 19: 226-234. 